\title{
EDUKASI AKUNTANSI DAN PELAPORAN KEUANGAN UMKM X DI ERA PANDEMI COVID19
}

\author{
1) amrie@pknstan.ac.id, Politeknik Keuangan Negara STAN* \\ 2) 1302190431_affan@pknstan.ac.id, Politeknik Keuangan Negara STAN \\ 3)1302190405_amalia@pknstan.ac.id, Politeknik Keuangan Negara STAN \\ 4) 1302190604_anandya@pknstan.ac.id, Politeknik Keuangan Negara STAN \\ 5) 1302190652_azka@pknstan.ac.id, Politeknik Keuangan Negara STAN \\ 6) 1302190407_christina@pknstan.ac.id, Politeknik Keuangan Negara STAN \\ 7) 1302190823_excella@pknstan.ac.id, Politeknik Keuangan Negara STAN \\ 8)1302190808_lutfiyatul@pknstan.ac.id, Politeknik Keuangan Negara STAN \\ 9) 1302191182_rudi@pknstan.ac.id, Politeknik Keuangan Negara STAN \\ 10)1302191364_niken@pknstan.ac.id,Politeknik Keuangan Negara STAN \\ 11) 1302191587_reyhan@pknstan.ac.id, Politeknik Keuangan Negara STAN \\ 12) 1302191484_teofani@pknstan.ac.id, Politeknik Keuangan Negara STAN \\ * untuk penulis korespondensi
}

Amrie Firmansyah'); Affan Muhammad Zulfa'); Amalia Eka Prastica ${ }^{\text {() }}$; Anandya Adina Nabila ${ }^{4)}$; Azka Rifqi Prasetya Aji ${ }^{5}$; Christina Happy Lukyani'); Excella Nala Amallia' ${ }^{\text {(); }}$ (Lutfiyatul Arifah ${ }^{8}$; Muhammad Rudi Andi ${ }^{9)}$; Niken Widyasari Permata Dewi ${ }^{10)}$; Reyhan Dharma Wijaya ${ }^{11)}$; Teofani Tesa Krisabel ${ }^{12}$

\begin{abstract}
This community service activity aims to provide education and assistance for MSMEs by providing an understanding of the basics of accounting, the use of Microsoft Excel accounting applications, and guidebooks in preparing financial reports. The method of implementing community service activities consists of the planning stage through observation and preliminary interviews with potential partners, the implementation of activities in the form of technical guidance. The final stage is monitoring which aims to accommodate the problems faced by MSME X in preparing financial reports independently. Based on the activities carried out, the owners of MSME $X$ are quite understanding in preparing financial reports.

Keywords: education, accounting, MSMEs, applications

\section{Abstrak}

Kegiatan pengabdian kepada masyarakat ini bertujuan untuk memberikan edukasi dan pendampingan bagi UMKM $\mathrm{X}$ dengan memberikan pemahaman dasar-dasar akuntansi, penggunaan aplikasi akuntansi Microsoft Excel, dan buku panduan dalam penyusunan laporan keuangan. Metode pelaksanaan kegiatan pengabdian kepada masyarakat terdiri dari tahap perencanaan yaitu dengan melakukan observasi dan wawancara pendahuluan dengan calon mitra. Tahap kedua merupakan inti dari pelaksanaan kegiatan berupa bimbingan teknis kegiatan PKM. Tahap ketiga adalah monitoring kegiatan yang bertujuan untuk menampung permasalahan yang dihadapi oleh UMKM X dalam menyusun laporan keuangan secara mandiri. Berdasarkan kegiatan yang telah dilakukan, pemilik UMKM X cukup memahami dalam menyusun laporan keuangan.
\end{abstract}

Kata Kunci : edukasi, akuntansi, UMKM, aplikasi

\section{PENDAHULUAN}

Usaha Mikro Kecil dan Menengah (UMKM) merupakan pilar penting dalam perekonomian Indonesia (Kemenko Perekonomian, 2021). Berdasarkan data Kementerian Koperasi dan UKM, per April 2021 jumlah UMKM mencapai 64,2 juta dengan kontribusi Produk Domestik Bruto (PDB) sebesar 61,07\% atau senilai 8.573,89 triliun rupiah (Kemenko Perekonomian, 2021). Kontribusi UMKM terhadap perekonomian Indonesia meliputi kemampuan menyerap $97 \%$ dari total tenaga kerja yang ada serta dapat menghimpun sampai 60,4\% dari total investasi (Kemenko Perekonomian, 2021). Berdasarkan potensi tersebut, Pemerintah Indonesia berusaha menggerakkan UMKM melalui program-program seperti pemberian bunga pinjaman, pemberian jaminan modal kerja, dan insentif perpajakan (Nainggolan, 2020). Dengan adanya program tersebut diharapkan para pelaku UMKM semakin giat dalam mengembangkan usahanya dan dapat menciptakan kehidupan masyarakat yang sejahtera. 


\section{PENGMASKU}

Volume 1 No. 1, Juni 2021

Kondisi UMKM di Indonesia secara keseluruhan mengalami penurunan akibat dampak pandemi covid19 (Bahtiar, 2021), walaupun beberapa UMKM masih memiliki strategi dalam meningkatkan penjualannya (Arham \& Firmansyah, 2021). Salah satu yang mampu bertahan dalam kondisi pandemi covid19 adalah UMKM di bidang kuliner. UMKM ini memiliki platform digital yang dapat meningkatkan efisiensi biaya. Selain itu, UMKM bidang kuliner dapat menambah saluran penjualan karena terbatasnya akses fisik dengan pelanggan akibat kebijakan social distancing. UMKM di bidang kuliner juga memiliki potensi pasar yang besar dan adanya permintaan yang terus-menerus, karena secara alamiah kebutuhan pangan merupakan kebutuhan dasar manusia (Farid et al., 2018).

Dalam menjalankan operasinya, salah satu permasalahan yang dihadapi UMKM adalah kurangnya pengetahuan pemilik UMKM akan pentingnya pelaporan keuangan (Firmansyah et al., 2020). Laporan keuangan UMKM dibutuhkan oleh penggunanya seperti kreditor, calon kreditor, investor atau calon investor dalam menilai kondisi keuangan UMKM. Apabila UMKM membutukan sumber pendanaan dari utang perbankan, maka perusahaan perbankan selaku pemberi pinjaman, membutuhkan laporan keuangan sebagai dasar analisis kelayakan keuangan UMKM. Walaupun saat ini tersedia beberapa aplikasi berbasis android dalam penyusunan laporan keuangan UMKM, namun pemilik UMKM masih banyak yang tidak familiar dengan aplikasi tersebut. Akibat kurangnya pengetahuan pemilik UMKM terkait dengan proses penyusunan laporan keuangan, pelaku UMKM masih melakukan pencatatan keuangan secara manual (Mashuri \& Ermaya, 2021). Selain itu, banyak pemilik UMKM kurang menyadari pentingnya pencatatan dan pelaporan keuangan UMKM (Istanti et al., 2020). Kondisi ini dapat mengakibatkan pemilik UMKM kurang dapat menyajikan infomasi dan data keuangan dengan andal. Selain itu, minimnya pengetahuan tentang pelaporan keuangan dapat berdampak pada UMKM mengalami kerugian.

Terkait dengan hal tersebut, salah satu kontribusi akademisi adalah melakukan pengabdian kepada masyarakat (PKM). PKN STAN yang memiliki kompetensi di bidang akuntansi dan keuangan perlu turut serta dalam memberikan kontribusi ilmu dan pengetahuan dalam pendampingan penyusunan laporan keuangan UMKM. Beberapa kegiatan PKM sebelumnya yang melakukan pendampingan penyusunan laporan keuangan UMKM dilaksanakan sebelum adanya pandemi covid19 (Firmansyah et al., 2019; Istanti et al., 2020; Krismayanti \& Marlina, 2021; Mashuri \& Ermaya, 2021; Muqorobin et al., 2019). Dalam kondisi pandemi covid19 bukan menjadi hal yang mudah dalam melakukan kegiatan PKM. Tuntutan dalam melaksanakaan tridarma pendidikan mengakibatkan civitas academica dengan memberikan manfaat atas ilmu dan pengetahuan yang dimiliki kepada masyarakat, tetap harus dilaksanakan.

PKM ini bertujuan untuk memberikan pendampingan kepada pemilik UMKM X dalam penyusunan laporan keuangan. UMKM X melakukan kegiatan menjual mie ayam dan bakso sapi yang beralamat di di Kabupaten Magelang. Pemilihan lokasi PKM di Kabupaten Magelang didasarkan bahwa para pelaku UMKM di Magelang mengalami kenaikan setiap tahun dalam volume produksi dan dapat mengalami perkembangan (Febrian \& Kristianti, 2020). Selain itu, sebagai salah satu destinasi pariwisata di Indonesia menjadi peluang bagi para pelaku UMKM untuk melakukan usaha untuk menjual berbagai produk khususnya di sektor kuliner (Febrian \& Kristianti, 2020).

Kegiatan PKM ini diharapkan UMKM mitra PKM dapat menyusun laporan keuangan sesuai dengan Standar Akuntansi Keuangan Entitas Mikro Kecil dan Menengah (SAK EMKM) yang dapat digunakan dalam mengetahui kondisi keuangan perusahaan. Pemilik UMKM selanjutnya dapat menggunakan laporan keuangan terkait dengan pengembangan strategi bisnisnya. Selain itu, laporan keuangan tersebut dapat digunakan dalam mengajukan sumber tambahan pendanaan baik kepada calon investor maupun kepada calon kreditor. 


\section{METODE PELAKSANAAN}

Metode yang digunakan dalam PKM kali ini sebenarnya sama yang dilakukan oleh (Firmansyah et al., 2019) yaitu tahap perencanaan, tahap pelaksanaan dan tahap monitoring. Kegiatan ini dilaksanakan pada tanggal yang meliputi tahap dilakukan secara tatap muka dengan pelaku UMKM. Tahap-tahap yang dilakukan meliputi pendahuluan berupa observasi pemilihan mitra, koordinasi Tim, koordinasi pelaksanaan PKM dengan UMKM. Berdasarkan observasi yang dilakukan oleh Tim, 7 dari 10 UMKM di bidang kuliner belum melakukan pencatatan transaksi dan penyusunan laporan keuangan. Pemilihan UMKM X sebagai mitra PKM didasarkan karena UMKM X belum memiliki laporan keuangan.

Tahap pelaksanaan merupakan kegiatan inti dari PKM kepada mitra UMKM X. Tahap pelaksanaan dilakukan tanggal 5 September 2021-10 September 2021. Tahap pelaksanaan ini meliputi kunjungan langsung ke UMKM X dengan memberikan pendampingan pencatatan transaksi dan penyusunan laporan keuangan secara manual, penyusunan laporan keuangan dengan menggunakan template Microsoft Excel. Selain itu, Tim KKM memberikan buku panduan, dan video penjelasan kepada mitra UMKM X. Template Microsoft Excel berisi langkah-langkah untuk menghitung harga pokok penjualan makanan dan minuman, menyusun laporan laba rugi, dan neraca yang sudah disesuaikan dengan SAK EMKM. Buku panduan berisi pedoman mengenai akuntansi laporan keuangan dan langkah-langkah dalam penggunaan Microsoft Excel. Video berisi penjelasan ringkas dan menarik mengenai UMKM dan edukasi penyusunan laporan keuangan. Selanjutnya, tahap monitoring dilakukan dengan tujuan untuk melihat perkembangan mitra UMKM dalam menerapkan pencatatan transaksi harian dan penyusunan laporan keuangan secara mandiri. Selain itu, pada tahap monitoring juga Tim PKM memberikan kesempatan bagi mitra UMKM X untuk melakukan konsultansi terkait dengan permasalahan dalam penyusunan laporan keuangan.

\section{PEMBAHASAN}

Setelah mitra UMKM X menyetujui untuk pelaksanaan PKM, Tim melakukan wawancara pendahuluan untuk mengidentifikasi masalah-masalah terkait dengan penyusunan laporan keuangan. Observasi dilakukan langsung ke lokasi UMKM X dan melakukan wawancara dengan pemilik UMKM X. Berdasarkan hasil wawancara tersebut, pemilik UMKM $\mathrm{X}$ tidak mengetahui tujuan dan proses penyusunan laporan keuangan. Selama ini, UMKM X hanya melakukan pencatatan secara manual dengan mencatat data penjualan dan pembelian barang yang dibutuhkan untuk menghasilkan produk. Data tersebut direkam atau direkap menggunakan aplikasi Microsoft Excel, namun pemilik UMKM X tidak melakukan penjurnalan dan tidak menyusun laporan keuangan. UMKM X tidak mengetahui pentingnya penyusunan laporan keuangan dan tidak memiliki pengetahuan dalam melakukan penyusunan laporan keuangan sesuai SAK EMKM. Selama beroperasi UMKM X hanya melakukan pencatatan sederhana dan manual tanpa adanya penyusunan laporan keuangan, pencatatan hanya menggunakan cash basis, tidak ada daftar akun yang digunakan dalam pencatatan, dan tidak ada pemisahan harta pribadi dengan usaha.

Permasalahan selanjutnya adalah pemilik UMKM X belum dapat memperhitungkan Harga Pokok Penjualan (HPP). UMKM X belum dapat menghasilkan HPP karena pemilik UMKM X tidak mengetahui formula perhitungannya. Selain itu, UMKM X belum menyusun laporan laba rugi, tidak adanya pencatatan pendapatan dan beban secara sistematis sesuai SAK EMKM, tidak adanya penyusunan laporan harga pokok penjualan, belum menyusun laporan posisi keuangan, tidak adanya pemisahan informasi akun terkait aset, liabilitas, dan ekuitas, hanya mencatat persediaan dan belanja setiap terjadi transaksi. 


\section{PENGMASKU}

Volume 1 No. 1, Juni 2021

Berdasarkan hasil observasi tersebut, Tim PKM menyusun aplikasi Microsoft Excel terkait dengan penyusunan laporan keuangan, buku panduan yang berisi tentang gambaran umum UMKM, akuntansi sesuai SAK EMKM, dan langkah-langkah penyusunan laporan keuangan, serta video penjelasan. penggunaan aplikasi microsoft excel dipilih karena penggunaannya mudah untuk dipelajari, fitur-fitur yang tersedia bisa menunjang penyusunan laporan keuangan, dapat menggunakan rumus-rumus excel sehingga penyusunan tidak perlu dilakukan secara manual satu per satu, lebih fleksibel dalam menambah atau mengurangi akunakun sesuai kebutuhan UMKM. Selain itu, penggunaan aplikasi Microsoft Excel memungkinkan asal-usul perhitungan bisa ditelusuri secara mudah dengan melihat formula perhitungan yang dibuat, sehingga alurnya dapat diikuti dengan jelas.

Kegiatan edukasi penyusunan laporan keuangan yang sesuai SAK EMKM, dilakukan secara langsung kepada Mitra UMKM X. Langkah-langkah penyusunan laporan keuangan dilakukan dengan langsung melibatkan interaksi antara anggota kelompok dengan mitra UMKM X dengan menggunakan Microsoft Excel yang sudah dibuat sesuai kondisi UMKM X dan ditunjang dengan penyediaan buku panduan yang menjelaskan proses pencatatan dan penyusunan laporan keuangan SAK EMKM secara rinci. Kegiatan penyampaian keluaran tersebut, memberikan dampak positif bagi penerima manfaat dan UMKM X. Pemilik dan pegawai UMKM $\mathrm{X}$ memiliki pemahaman baru tentang pengoperasian Microsoft Excel sehingga bisa melakukan penjurnalan atas transaksi yang terjadi, hingga akhirnya bisa menyusun laporan keuangan UMKM dengan akurat dan sesuai, tidak lagi secara manual.

Kondisi pencatatan akuntansi UMKM X dari awal operasi hingga awal bulan Agustus 2021, hanya melakukan pendataan dan pencatatan atas daftar pembelian bahan baku dan penjualan produk makanan setiap harinya secara manual. Setelah pendataan dilakukan, pihak mitra melakukan rekap sederhana menggunakan Microsoft Excel. Selain itu, mitra UMKM X juga tidak menghitung Harga Pokok Penjualan karena tidak memiliki pemahaman tentang perhitungannya. Permasalahan yang terjadi adalah terdapat data pembelian bahan baku yang tidak dicantumkan dalam Microsoft Excel karena penulisan di buku pendataan kurang jelas, terdapat beberapa transaksi pembelian bahan baku dan penjualan produk yang tidak bisa direkap secara akurat sesuai tanggal transaksi, karena penulisan di buku kurang terstruktur atau tercampur dengan data-data hari sebelumnya, kesulitan dalam menentukan laba atau rugi dalam usahanya karena sebelumnya tidak memperhitungkan HPP. Adanya keterbatasan tersebut menyebabkan mitra UMKM X tidak dapat menghasilkan laporan keuangan sesuai SAK EMKM. Kondisi ini dapat berdampak dalam pengembangan usaha jangka panjang. Keluaran yang dihasilkan dari kegiatan PKM ini diserahkan kepada mitra UMKM X untuk digunakan sebagai panduan dalam pencatatan transaksi dan penyusunan laporan keuangan.

Berdasarkan hasil monitoring yang dilakukan oleh Tim PKM, pemilik UMKM X cukup memahami dalam melakukan pencatatan transaksi pembelian dan penjual setiap hari melalui penjurnalan yang secara otomatis tercatat dalam laporan keuangan untuk periode saat ini. Dalam kegiatan monitoring, tidak terdapat adanya masalah yang ditemukan sebelumnya, sehingga hasil keluaran PKM dapat berguna bagi mitra UMKM X. Setelah menerapkan proses pelaporan keuangan sebagaimana yang diberikan oleh Tim PKN, perkembangan usaha mitra UMKM X dapat terpantau dengan baik, dan laba bersih dari hasil penjualannya dapat diketahui secara akurat. Kondisi ini menunjukkan kemajuan atas pelaporan keuangan UMKM X yang cukup baik karena sebelum kegiatan PKM, UMKM X hanya melakukan pencatatan transaksi pembelian dan penjualan secara manual di buku sehingga laba dari hasil penjualan yang diterima hanya berdasarkan perkiraan saja dengan nominal hasil pembulatan yang menyebabkan pemilik UMKM $X$ sulit untuk mengembangkan usahanya karena ketidakakuratan laba, tidak dicatatnya beberapa transaksi, dan terdapat sebagian data yang hilang. 


\section{SIMPULAN}

Kegiatan Pengabdian Kepada Masyarakat dilakukan oleh Tim PKM dari PKN STAN, dengan topik pemdampingan dalam penyusunan laporan keuangan pada UMKM X. Kegiatan ini dilakuan dalam 3 tahap yaitu tahap perencanaan, tahap pelaksanaan dan tahap monitoring. Berdasarkan kegiatan ini, pemilik UMKM X mendapatkan manfaat dalam memahami proses pelaporan keuangan dan mengatasi masalah terkait dengan akuntansi pada periode sebelumnya. PKM selanjutnya dapat dilakukan pada UMKM sejenis atau UMKM lainnya terkait dengan edukasi akuntansi dan pelaporan keuangan UMKM.

\section{DAFTAR PUSTAKA}

Arham, A., \& Firmansyah, A. (2021). Strategi peningkatan ekspor UMKM Indonesia selama pandemi Covid-19. Media Mahardhika, 20(1), 50-68. https://doi.org/10.29062/mahardika.v20i1.300

Bahtiar, R. A. (2021). Dampak pandemi covid-19 terhadap sektor usaha mikro, kecil dan menengah serta solusinya. Info Singkat, 13(2), 1-6. https://berkas.dpr.go.id/puslit/files/info_singkat/Info Singkat-XIII-10-II-P3DI-Mei-20211982.pdf

Farid, A., Romadi, U., \& Witono, D. (2018). Faktor-faktor yang mempengaruhi adopsi petani dalam penerapan sistem tanam jajar legowo di Desa Sukosari Kecamatan Kasembon Kabupaten Malang Provinsi Jawa Timur. Jurnal Penyuluhan, 14(1), 27-32. https://doi.org/10.25015/penyuluhan.v14i1.19226

Febrian, L. D., \& Kristianti, I. (2020). Identifikasi Faktor eksternal dan internal yang mempengaruhi perkembangan UMKM (studi kasus pada UMKM di Kabupaten Magelang). Journal of Economic, Management, Accounting and Technology, 3(1), 23-35. https://doi.org/10.32500/jematech.v3i1.799

Firmansyah, A., Arham, A., \& Nor, A. M. E. (2019). Edukasi akuntansi dan bimbingan teknis penyusunan laporan keuangan usaha mikro, kecil, dan menengah. Wikrama Parahita: Jurnal Pengabdian Masyarakat, 3(2), 57-63. https://doi.org/10.30656/jpmwp.v3i2.1766

Firmansyah, A., Arham, A., \& Nor, A. M. E. (2020). The implementation of micro, small, and medium enterprises accounting in Indonesia. In Public Sector Accountants and Quantum Leap: How Far We Can Survive in Industrial Revolution 4.0? (pp. 64-70). Taylor and Francis Group. https://doi.org/10.1201/9780367822965

Istanti, L. N., Agustina, Y., Wijijayanti, T., \& Dharma, B. A. (2020). Pentingnya penyusunan laporan keuangan umkm bagi para pengusaha bakery, cake and pastry (BCP) di Kota Blitar. Jurnal Graha Pengabdian, 2(2), 163-171. http://journal2.um.ac.id/index.php/jgp/article/view/13350

Kemenko Perekonomian. (2021). UMKM menjadi pilar penting dalam perekonomian Indonesia. https://ekon.go.id/publikasi/detail/2969/umkm-menjadi-pilar-penting-dalamperekonomian-indonesia

Krismayanti, E., \& Marlina, T. (2021). Pendampingan penerapan standar akuntansi keuangan EMKM dalam penyajian laporan keuangan UMKM sebagai salah satu dasar pengajuan kredit pinjaman bank. Jurnal Abdimas Dedikasi Kesatuan, 2(1), 27-36. https://doi.org/10.37641/jadkes.v2i1.474

Mashuri, A. S., \& Ermaya, H. N. L. (2021). Peningkatan kualitas penyusunan laporan keuangan manual menjadi digitalisasi akuntansi sederhana pada pelaku UMKM di Kabupaten Serang. Jurnal Bakti Masyarakat Indonesia, 4(1), 92-101. https://doi.org/10.24912/jbmi.v4i1.9501

Muqorobin, M. M., Wahyuni, P., Simangunsong, M. E., \& Cahyani, I. N. (2019). Pendampingan pembuatan laporan keuangan berdasarkan SAK dan UMKM Go-Online 


\section{PENGMASKU}

Volume 1 No. 1, Juni 2021

pada UKM. Jurnal Graha Pengabdian, 1(1), 51-55. http://journal2.um.ac.id/index.php/jgp/article/view/9964

Nainggolan, E. U. P. (2020). UMKM bangkit, ekonomi Indonesia terungkit. https://www.djkn.kemenkeu.go.id/artikel/baca/13317/UMKM-Bangkit-EkonomiIndonesia-Terungkit.html

\section{Lampiran}

Survei data lapangan berupa aset, liabilitas, dan ekuitas serta profil narasumber mengenai pemahaman dan penerapan akuntansi UMKM yang dilakukan pada hari Kamis, 1 September 2021.
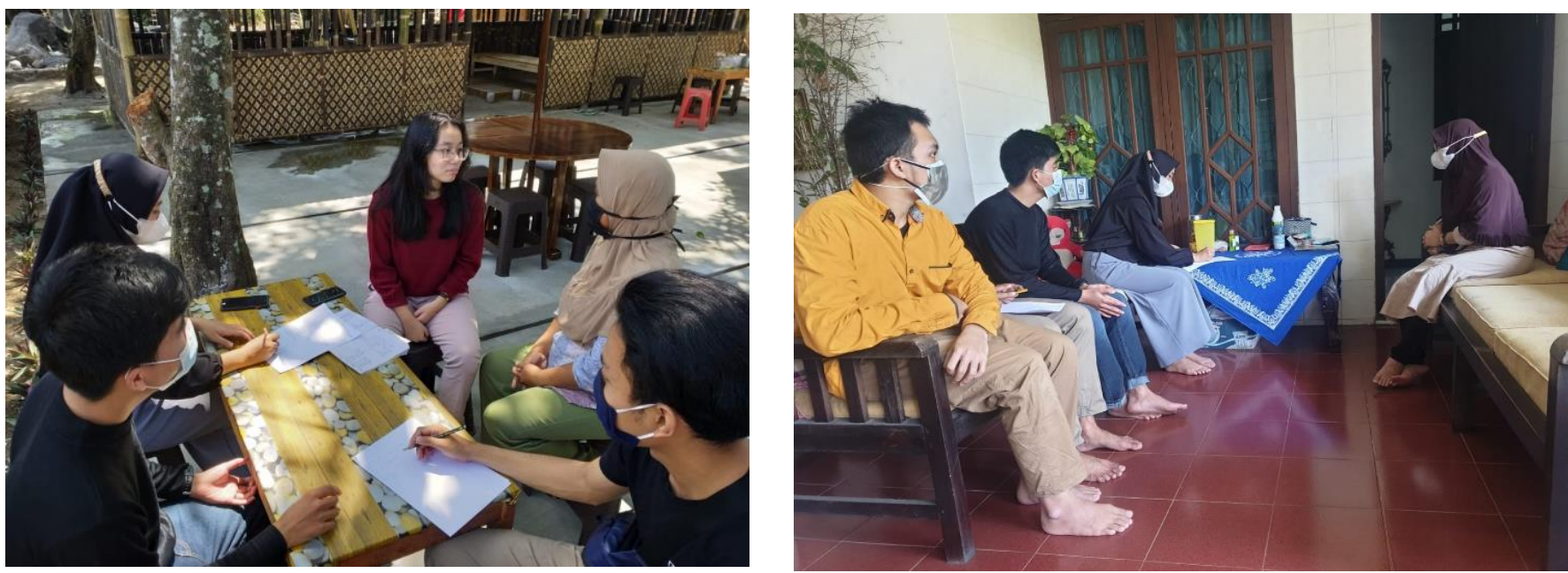

Proses edukasi dan penyerahan keluaran kepada penerima manfaat.
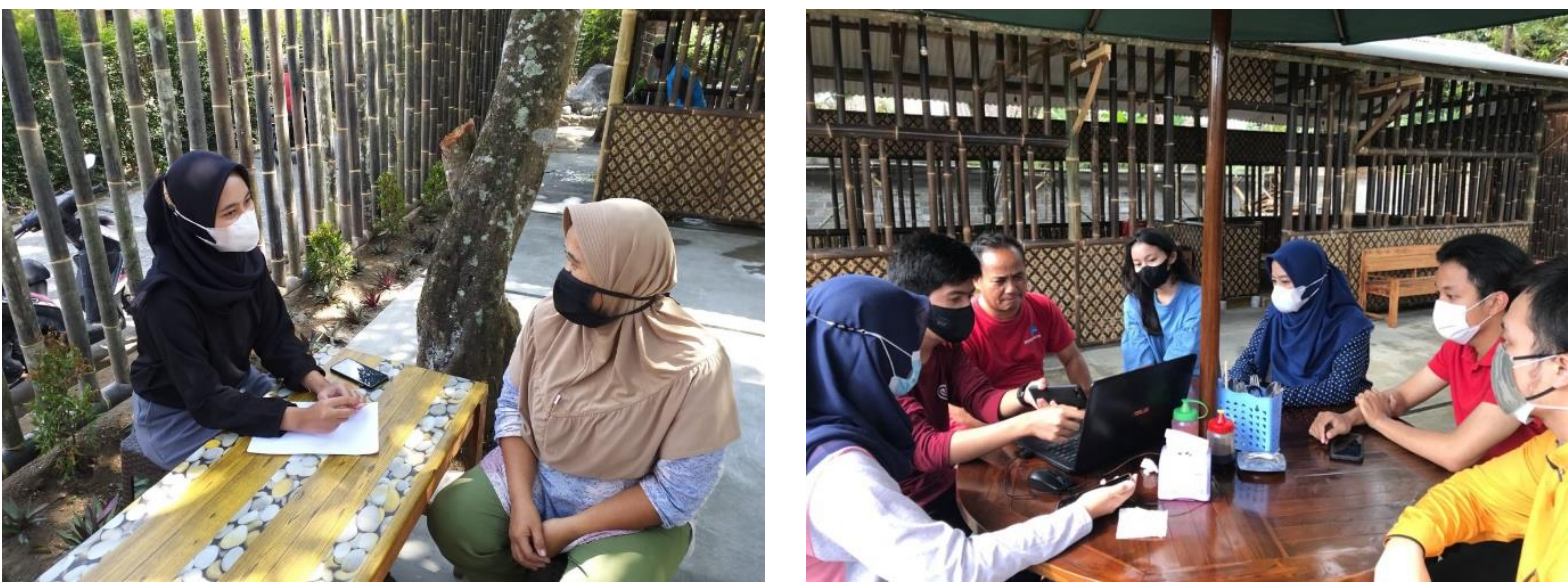


\section{PENGMASKU}

Volume 1 No. 1, Juni 2021
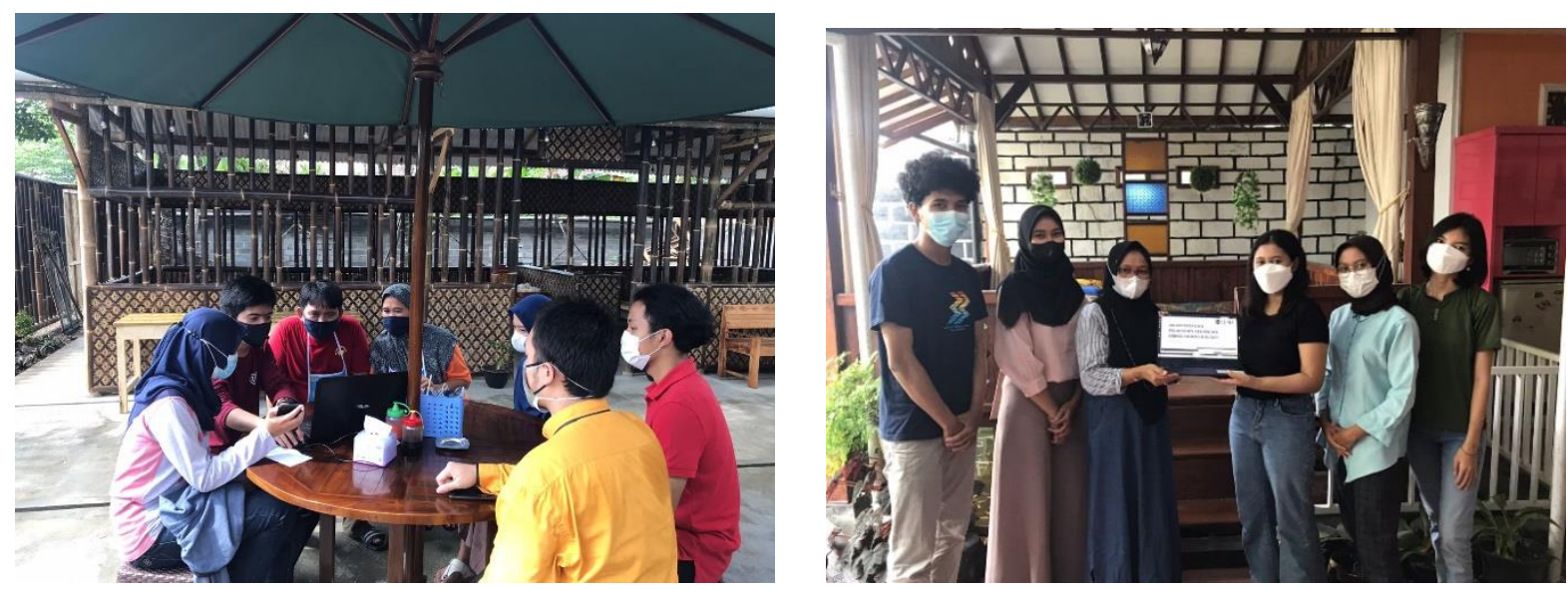

Hasil keluaran berupa buku panduan.

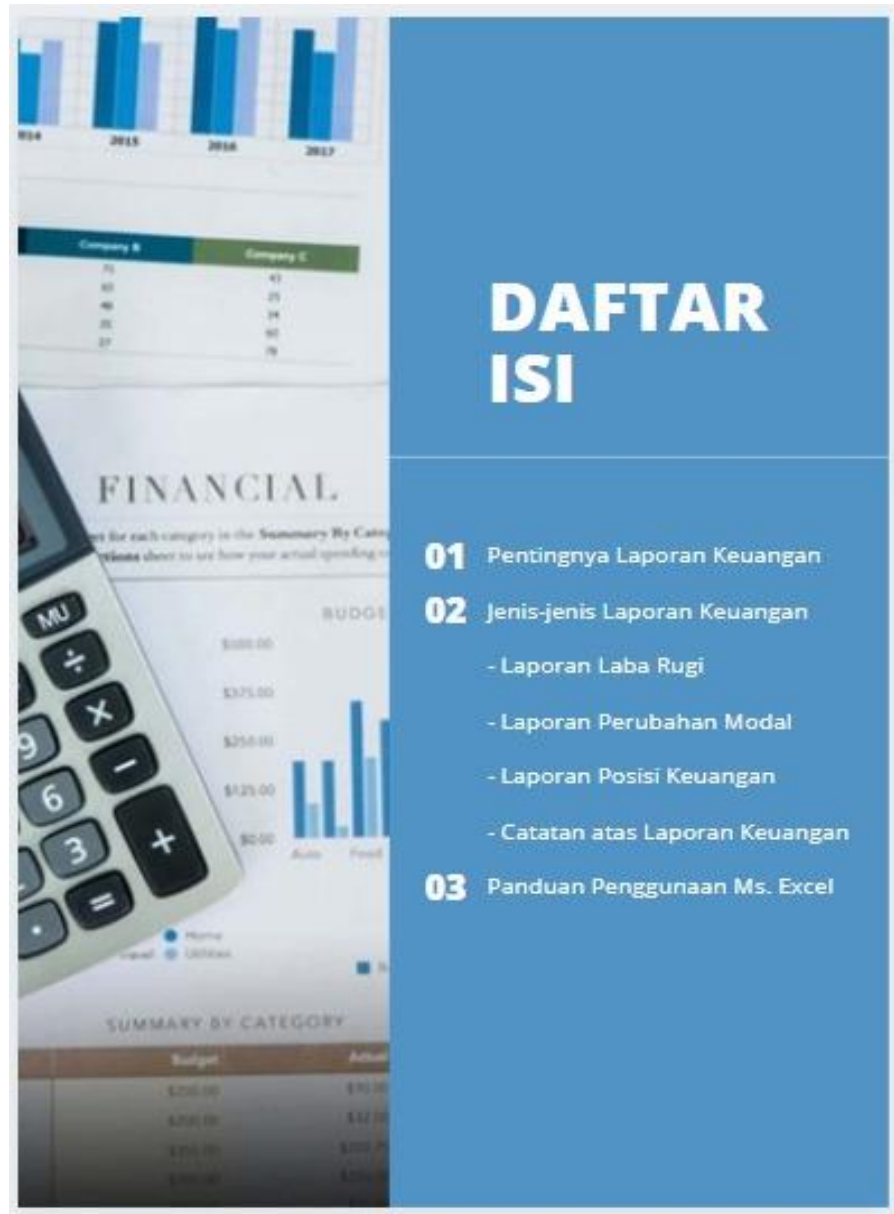

